\title{
OCCUPATIONAL ASTHMA FOLLOW-UP - WHICH MARKERS ARE ELEVATED IN EXHALED BREATH CONDENSATE AND PLASMA?
}

\author{
DANIELA PELCLOVÁ ${ }^{1}$, ZDENKA FENCLOVÁ', ŠTĚPÁNKA VLČKOVÁ', PAVLÍNA KLUSÁČKOVÁ ${ }^{1}$, \\ JINDŘIŠKA LEBEDOVÁ ${ }^{1}$ KAMILA SYSLOVÁ ${ }^{2}$, JAROMÍR BĚLÁČEK ${ }^{3}$, MAREK KUZMA ${ }^{4}$, TOMÁŠ NAVRÁTIL', \\ SERGEY ZAKHAROV ${ }^{1}$, and PETR KAČER ${ }^{2}$
}

${ }^{1}$ Charles University in Prague and General University Hospital, Prague, Czech Republic

Department of Occupational Medicine of the First Faculty of Medicine

${ }^{2}$ Institute of Chemical Technology, Prague, Czech Republic

${ }^{3}$ Charles University in Prague and General University Hospital, Prague, Czech Republic

Institute of Biophysics and Informatics of the First Faculty of Medicine

${ }^{4}$ Institute of Microbiology of the AS CR, v. v. i., Prague, Czech Republic

${ }^{5}$ J. Heyrovský Institute of Physical Chemistry of the AS CR, v. v. i., Prague, Czech Republic

Department of Biophysical Chemistry

\begin{abstract}
Objectives: To search for optimal markers in the exhaled breath condensate (EBC), plasma and urine that would reflect the activity/severity of occupational asthma (OA) after the withdrawal from the exposure to the allergen. Material and Methods: Markers of oxidative stress: 8-iso-prostaglandin $\mathrm{F}_{2 \alpha}$ (8-isoprostane, 8-ISO), malondialdehyde (MDA), 4-hydroxy-trans-2-nonenale (HNE), cysteinyl leukotrienes (LT) and $\mathrm{LTB}_{4}$ were determined using liquid chromatography and mass spectrometry in 43 subjects with immunological OA $(49.3 \pm 11.8$ years), removed from the exposure to the sensitizing agent $10.5 \pm 6.5$ years ago; and in 20 healthy subjects ( $49.0 \pm 14.9$ years). EBC was harvested both before and after the methacholine challenge test. In parallel, identical markers were collected in plasma and urine. The results were analyzed together with forced expiratory volume in one second $\left(\mathrm{FEV}_{1}\right)$, blood eosinophils, immunoglobulin $\mathrm{E}(\mathrm{IgE})$ and eosinophilic cationic protein $(\mathrm{ECP})$ and statistically evaluated (Spearman rank correlation $\mathrm{r}_{\mathrm{s}}$, two- or one-sample $\mathrm{t}$ tests and alternatively Kruskal Wallis or pair Wilcoxon tests). Results: Several parameters of lung functions were lower in the patients (FEV1\% predicted, MEF25\% and MEF50\%, Rtot $\%$, $\mathrm{p}<0.001)$. Shorter time interval since the removal from the allergen exposure correlated with higher ECP $\left(\mathrm{r}_{\mathrm{S}}=0.375\right)$ and lower $\mathrm{FEV}_{1} \%, \mathrm{MEF} 25 \%$ and MEF50\% after methacholine challenge $\left(\mathrm{r}_{\mathrm{s}}=-0.404,-0.425\right.$ and -0.532 , respectively). In the patients, IgE ( $<<0.001)$ and ECP $(p=0.009)$ was increased compared to controls. In EBC, 8-ISO and cysteinyl LTs were elevated in the asthmatics initially and after the challenge. Initial 8-ISO in plasma correlated negatively with $\mathrm{FEV}_{1}\left(\mathrm{r}_{\mathrm{S}}=-0.409\right)$ and with methacholine $\mathrm{PD}_{20}\left(\mathrm{r}_{\mathrm{S}}=-0.474\right)$. 8-ISO in plasma after the challenge correlated with $\operatorname{IgE}\left(\mathrm{r}_{\mathrm{S}}=0.396\right)$. Conclusions: The improvement in OA is very slow and objective impairments persist years after removal from the exposure. Cysteinyl LTs and 8-ISO in EBC and 8-ISO in plasma might enrich the spectrum of useful objective tests for the follow-up of OA.
\end{abstract}

Key words:

Occupational asthma, Exhaled breath condensate, Eosinophilic cationic protein, 8-isoprostane, Leukotrienes, Methacholine

Study support was provided by the Research Project of the Charles University in Prague P28/LF/6 and EU Project "Material-technical Research Base for the Diagnostics and Treatment of Environmentally-caused and Oncological Disorders and their Risks, in the General University Hospital in Prague” (reg. No. CZ.2.16/3.1.00/24012) from OP Prague Competitiveness. Manager of project: Jan Malík, Professor, MD, PhD.

Received: October 12, 2012. Accepted: January 21, 2014.

Corresponding author: D. Pelclová, Charles University in Prague and General University Hospital, Department of Occupational Medicine of the First Faculty of Medicine, Na Bojišti 1, 12000 Prague, Czech Republic (e-mail: daniela.pelclova@lf1.cuni.cz). 


\section{OBJECTIVES}

Asthma is considered to be a chronic inflammatory disease, however evaluation and therapy guidance are mainly based on clinical symptoms and lung function test that remain the cornerstones of clinical practice. On the other hand, occupational asthma (OA) needs more objective signs for its evaluation due to its broad socioeconomic aspects.

In the Czech Republic, the numbers of OA have been relatively stable during the past 20 years. In 2012, 58 cases of $\mathrm{OA}$ and/or allergic rhinitis have been acknowledged. Most frequent allergens causing OA were isocyanates ( 23 cases) and flour ( 6 cases) [1].

The patients with OA are withdrawn from the exposure to the respective allergen; therefore OA represents a model of asthma useful for study after allergen elimination. If it does not concern ubiquitous allergens, a more favorable prognosis is usually expected [2]. However, only a smaller proportion of the subjects experience a clearing of asthma [3]; in our patients, the symptoms resolved in $13.5 \%$ patients only [4].

During the follow-ups of the subjects with OA, it is a challenge to evaluate the severity of the disorder [4] because in case of the OA impairment the patient gets additional financial compensation. Therefore, it is crucial to find objective markers [5-7] that are not susceptible to malingering. The fraction of exhaled $\mathrm{NO}(\mathrm{FeNO})$ is the most extensively studied biomarker, however it is related primarily to eosinophilic inflammation and decreases after corticosteroid treatment [8]. Induced sputum is another candidate biomarker; after the withdrawal from the contact with the sensitizing agents it shows lower inflammation in patients with eosinophillic, but not neutrophillic inflammation [9]. Exhaled breath condensate (EBC) testing may be considered a candidate method to be used for objective evaluation of the inflammatory process in the airways [10]. As a rich source of a variety of substances indicative of changes in the environment of the airways, it offers further possibilities for the diagnosis and monitoring. There is an increasing body of evidence that the changes in the level of the markers in EBC reflect local abnormalities of the airway lining fluid $[11,12]$.

Cysteinyl leukotrienes (LT) - $\mathrm{LTC}_{4}, \mathrm{LTD}_{4}$, and $\mathrm{LTE}_{4}$ are biosynthesized from arachidonic acid through the action of 5-lipoxygenase and may represent mediators of airway obstruction [13], inflammation and fibrosis. On the other hand, $\mathrm{LTB}_{4}$ activates leukocytes and its level increases during exacerbation of chronic obstructive pulmonary disease (COPD) and after smoking [14].

The 8-iso-prostaglandin $\mathrm{F}_{2 a}$ (8-isoprostane, 8-ISO) is a stable oxidative stress marker, formed nonenzymatically by oxidation of arachidonic acid [15]. Levels of 8-ISO are increased in EBC of asthmatic patients and correlate with disease severity, without being suppressed by corticosteroid treatment [16,17] and in pneumoconioses where oxidative stress plays an important role. This marker should reflect also non-eosinophilic inflammation and involves small airways function, thus suggesting that it may be used complementarily to spirometry for the monitoring of patients with asthma [18]. The quantification of oxidative stress can also be achieved by determination of aldehydes, such as malondialdehyde (MDA) and 4-hydroxy-trans2-nonenale (HNE).

The aim of the study was to search for optimal markers in the EBC, plasma and urine that would reflect the severity of the disease and distinguish between a stable asthma and asthma with signs of activity.

\section{MATERIAL AND METHODS}

\section{Subjects}

Forty-three subjects with previously diagnosed immunological OA (18 men, 25 women, mean age: $49.3 \pm 11.8$ years) after withdrawal from the occupational allergen exposure for average $10.5 \pm 6.5$ years were examined. Among them, 24 had been exposed to: 
- high molecular weight (HMW) allergens - 7x wheat and/or rye flour, $2 \times$ feathers dust, $2 \times$ poultry dust, $1 \times$ : grain dust, straw, cow dust, mouse hairs, peanut dust, culture medium, wood dust, cotton, synthetic fibers, tea dust, mites, latex paint, acetal homopolymer;

- 19 low molecular weight (LMW) allergens - 3x aluminum potassium fluoride flux, $3 \times$ lasamide-2,4-dichloro-5-sulfamoylbenzoic acid [2], $3 \times$ isocyanates, $2 \times$ ostazine dye, $1 \times$ welding fumes, chypsine, frite, hydrazine, glutaraldehyde, aziridine, plastisol, and 3-nitro-benzenesulfonyl chloride.

All had been diagnosed with OA (but not occupational rhinitis) at the first hospitalization if a decrease of forced expiratory volume in one second $\left(\mathrm{FEV}_{1}\right)$ of $20 \%$ was found during the specific challenge test. This test was performed in the exposure chamber for $30 \mathrm{~min}$, using the materials from patients' workplace collected by occupational hygienists from the Public Health department. If the work could not have been simulated in the exposure chamber, patients have been exposed at their workplace for $2 \mathrm{~h}$. Spirometry was measured before and after specific bronchoprovocation challenges during $24 \mathrm{~h}$. In addition to spirometry, following parameters had been used at the time of diagnosis: blood eosinophils, total immunoglobulin $\mathrm{E}$ ( $\mathrm{IgE})$, non-specific bronchial hyperresponsiveness, and skin prick test reactivity (to environmental and occupational allergens, if available) [19].

Asthma severity, combining the clinical severity score and treatment according to the Global Initiative for Asthma [20] was evaluated at the time of diagnosis and at the last follow-up examination. The results of prick test and the number of positive results of allergens were compared at the two first and last examinations.

Control group consisted of 20 subjects, working as office or health care employees and having no symptoms of asthma (10 men, 10 women, mean age: $49 \pm 14.9$ years).

All subjects were examined according to the following pattern: physical examination and a standardized questionnaire with personal and occupational history, treatments, smoking, and recording of meals and alcoholic beverages consumed during the day preceding the day of examination; and collection of EBC, urine and blood samples.

\section{Lung function}

Spirometry and body plethysmography tests were performed using the MasterLab unit (Jaeger, Germany) in line with the European Respiratory Society recommendations [21]. Resting spirometry was carried out four times during $24 \mathrm{~h}$.

The non-specific bronchoprovocation test was performed with methacholine using the Jaeger dosimeter method (Asthma Provocation System) according to Cockcroft [22]. Methacholine 3.2\% was inhaled at following doses: $0.05 \mathrm{mg}, 0.35 \mathrm{mg}, 1 \mathrm{mg}, 1.5 \mathrm{mg}, 1.5 \mathrm{mg}$, and $1.5 \mathrm{mg}$. A decrease in $\mathrm{FEV}_{1}$ of $20 \%$ was considered a positive result $[23,24]$.

Exhaled breath condensate (EBC) was collected within the following 15-20 min with EcoScreen, Jaeger, for the analysis of the markers both before and after the methacholine challenge test. All subjects (wearing a nose-clip) breathed tidally through a mouthpiece connected to the condenser $\left(-20^{\circ} \mathrm{C}\right)$, where vapors, aerosols and moisture condensed along the walls of the tube [11]. A constant volume of 1201 of exhaled air was maintained. Immediately after the sample collection, its volume was measured, and $250 \mathrm{pg}$ of $\mathrm{LTE}_{4}-d_{3}$ was added to $1 \mathrm{ml}$ of EBC as deuterium labeled internal standard (stable-isotope-dilution assay). Samples were immediately frozen to $-80^{\circ} \mathrm{C}$ and stored for a period not exceeding 2 months. The study was carried out according to the Helsinki Declaration of 1975, as revised in 1983. The Ethics Committee of the First Faculty of Medicine, Charles University, approved all examinations and tests, and all of the study subjects had given their written informed consent for all tests and examinations. 
Analysis of LTs was performed as previously described $[25,26]$. Briefly, the method consists of a pre-treatment step, immunoaffinity extraction (IAE) for rapid and effective isolation of biomarkers from the biological matrices (EBC, plasma and urine) and a detection procedure using liquid chromatography - electrospray ionization - tandem mass spectrometry (LC-ESI-MS/MS). The mobile phase consisting of a 70:30 (v/v) acetonitrile:water mixture adjusted to $\mathrm{pH} 11$ with triethylamine was used for isocratic elution at a flow rate of $250 \mu \mathrm{l} / \mathrm{min}$. The UHPLC system consisted of a Hypercarb Thermo $(100 \times 2.1 \mathrm{~mm} \times 5 \mu \mathrm{m})$ column connected to a Hypercarb pre-column (Thermo Electron Corporation, USA). A mass spectrometer TSQ Vantage (Thermo Scientific, USA) was used as a detector operating with electrospray ionization in negative mode $\left(\mathrm{ESI}^{-}\right)$. For the measurement of cysteinyl LTs and deuterated ISs, the selected reaction monitoring (SRM) mode was used. The method was characterized by a high precision $<93.3 \%$ and an acceptable accuracy $<90.3$. The limit of detection was $1-2 \mathrm{pg} / \mathrm{ml}$ in EBC, $5-8 \mathrm{pg} / \mathrm{ml}$ in plasma and $12-18 \mathrm{pg} / \mathrm{ml}$ in urine.

Analysis of 8-ISO, MDA and HNE was performed as previously described [27,28]. Briefly, the method consists of a pre-treatment step, solid phase extraction (SPE) used for rapid and effective isolation of biomarkers from the biological matrices (EBC, plasma and urine) and a detection procedure using ultra high potential liquid chromatography - electrospray ionization - tandem mass spectrometry (UHPLC-ESI-MS/MS). The mobile phase acetonitrile and water with $0.1 \%$ formic acid at a ratio of $70: 30(\mathrm{v} / \mathrm{v})$ was used for isocratic elution at a flow rate of $400 \mu \mathrm{l} / \mathrm{min}$. The UHPLC analysis was carried out using a Kinetex C182.7 $\mu \mathrm{m}$ $100 \AA ̊$ A column $(50 \times 2.1 \mathrm{~mm})$ (Phenemonex, USA). A triple quadrupole mass spectrometer TSQ Vantage (Thermo Scientific, USA) was used as a detector operating with electrospray ionization in negative mode $\left(\mathrm{ESI}^{-}\right)$.

The deuterium-labelled analogues of the biomarkers were used for the measurement. The method was characterized by a high precision $<89.9 \%$ and an acceptable accuracy $<89.6 \%$. Optimized conditions established the limits of detection at $2 \mathrm{pg} / \mathrm{ml}, 21 \mathrm{ng} / \mathrm{ml}$ and $26 \mathrm{ng} / \mathrm{ml}$ of the EBC for the most prominent oxidative stress markers 8-ISO, MDA, and 4-HNE respectively. The limit of detection was $3 \mathrm{pg} / \mathrm{ml}$ for 8 -ISO, $31 \mathrm{ng} / \mathrm{ml}$ for MDA, $38 \mathrm{ng} / \mathrm{ml}$ for HNE in plasma and $17 \mathrm{pg} / \mathrm{ml}$ for $8-\mathrm{ISO}, 87 \mathrm{ng} / \mathrm{ml}$ for MDA and $91 \mathrm{ng} / \mathrm{ml}$ for HNE in urine.

The contamination of the EBC with saliva was excluded by measuring the concentration of alpha-amylase (UV-VIS absorption spectroscopy). The $\mathrm{pH}$ of the EBC was measured using a compact pH-meter (InoLab,WTW, Germany), a standardized method for the determination of $\mathrm{pH}$ in the EBC. This method consists of de-aeration step with argon followed by the $\mathrm{pH}$ measurement. The conditions of de-aeration were as follows: argon flow $21 \mathrm{l} / \mathrm{h}$, total time of de-aeration $10 \mathrm{~min}$. The accuracy of the measurement was \pm 0.01 .

Blood and urine analysis. Blood and spot urine samples were collected before and after the methacholine challenge test for following parameters: erythrocyte sedimentation (ESR), 8-ISO, MDA, HNE, cysteinyl LTs and $\mathrm{LTB}_{4}$ in plasma and urine. $\mathrm{C}$ reactive protein (CRP), eosinophils in the blood, IgE, and eosinophilic cationic protein (ECP) were measured before the challenge test.

\section{Statistics}

Both discrete and continuous variables were included in the present study. Basic descriptive statistics (mean, mode, median, range, minimum, maximum, standard deviation) were calculated in continuous variables. Subsequently, the normal distribution of all variables was tested using sample skewness, kurtosis and the Kolmogorov-Smirnov test. Furthermore, the Pearson product moment correlation $\left(r_{p}\right)$ and Spearman rank correlation $\left(r_{S}\right)$ were used for normally and non-normally distributed variables, respectively. Moreover, correlations were calculated separately for selected markers in both groups. The Spearman correlation 
was used to analyze the relationships between pairs of continuous variables.

Two- or one-sample t-tests were used to compare differences between the groups or within trials. In the event of non-normally distributed variables, the Kruskal-Wallis or one-sample Wilcoxon tests were used as nonparametric alternatives. The statistical significance of the correlations was tested on three levels: $p<0.05, p<0.01$ and $\mathrm{p}<0.001$. All analyses were conducted and verified in SPSS 17.0 (SPSS Inc., Chicago, IL, USA).

\section{RESULTS}

The groups studied did not significantly differ in age, gender, or smoking, as can be seen in Table 1, but asthmatic symptoms and medication for asthma (topical corticosteroids) were found in the group of patients only (Table 2).
The evaluation of OA severity at the time of diagnosis in the subjects occupationally exposed to HMW allergens was grade 2 in $79 \%$, grade 3 in $21 \%$, and no grade 4 . In the subjects exposed to LMW agents, grade 2 was found in $84 \%$, grade 3 in $11 \%$ and grade 4 in $5 \%$ of patients.

In the subjects with OA due to HMW agents, prick test at the time of diagnosis were positive in $91.7 \%$ and in the subjects with OA due to LMW agents in $57.9 \%$.

The results of blood, EBC and urine analysis in both groups are shown in Table 3. Several parameters of lung functions were significantly impaired in the patients followed for OA. $\mathrm{FEV}_{1}$ after the methacholine test was significantly lower in subjects with OA, as can be seen in Table 3. Shorter time interval since the removal from the allergen exposure correlated with higher ECP $\left(\mathrm{r}_{\mathrm{s}}=0.375\right)$, and lower $\mathrm{FEV}_{1} \%$, $\mathrm{MEF} 25 \%$ and MEF50\% after methacholine challenge $\left(\mathrm{r}_{\mathrm{S}}=-0.404,-0.425\right.$ and -0.532 , respectively).

Table 1. Description of the group of occupational asthma patients and of the control group

\begin{tabular}{lcccccc}
\hline \multirow{2}{*}{ Parameters } & \multicolumn{3}{c}{ Occupational asthma group } & \multicolumn{3}{c}{ Control group } \\
\cline { 2 - 7 } & total & men & women & total & men & women \\
\hline Study group (n) & 43 & 18 & 25 & 20 & 10 & 10 \\
Age (years), $\mathrm{M} \pm \mathrm{SD}$ & $49.3 \pm 11.8$ & $49.9 \pm 9.4$ & $48.8 \pm 11.7$ & $49.0 \pm 14.9$ & $46.3 \pm 18.6$ & $51.6 \pm 7.9$ \\
Smoking (yes/no) & $6 / 37$ & $2 / 16$ & $4 / 21$ & $3 / 17$ & $0 / 10$ & $3 / 7$ \\
$\begin{array}{l}\text { History of occupational exposure } \\
\text { to HMW/LMW agents }\end{array}$ & $24 / 19$ & $7 / 11$ & $17 / 8$ & n.a. & n.a. & n.a. \\
\hline
\end{tabular}

M - mean; SD - standard deviation.

HMW - high molecular weight; LMW - low molecular weight.

n.a. - not applicable.

Table 2. Treatment and symptoms in the subjects with occupational asthma and in the control group

\begin{tabular}{|c|c|c|c|c|c|c|}
\hline \multirow[t]{2}{*}{ Parameters } & \multicolumn{3}{|c|}{$\begin{array}{l}\text { Occupational asthma group } \\
\text { (n) }\end{array}$} & \multicolumn{3}{|c|}{$\begin{array}{l}\text { Control group } \\
\text { (n) }\end{array}$} \\
\hline & total & men & women & total & men & women \\
\hline Current asthmatic symptoms & 42 & 18 & 24 & 0 & 0 & 0 \\
\hline Corticosteroids (inhaled) & 39 & 17 & 22 & 0 & 0 & 0 \\
\hline Antihistaminic drugs & 18 & 2 & 16 & 0 & 0 & 0 \\
\hline Bronchodilators & 43 & 18 & 25 & 0 & 0 & 0 \\
\hline
\end{tabular}


In the asthmatics, differently from the controls, $\mathrm{EBC} \mathrm{pH}$ became more acidic after the methacholine challenge, as can be seen in Table 3. Total cysteinyl LTs, LTC $_{4}$ and MDA in the $\mathrm{EBC}$ before the challenge were higher in OA patients. In addition, 8-ISO was elevated in the EBC of asthmatics both before and after the challenge. Initial 8-ISO in the plasma negatively correlated with $\mathrm{FEV}_{1}\left(\mathrm{r}_{\mathrm{S}}=-0.409\right)$ and with methacholine $\mathrm{PD}_{20}\left(\mathrm{r}_{\mathrm{S}}=-0.474\right)$. Additionally, 8-ISO in plasma after the challenge correlated with $\operatorname{IgE}\left(\mathrm{r}_{\mathrm{S}}=0.396\right)$.

Blood eosinophils (absolute number) in the asthmatics correlated with the impairment of $\mathrm{FEV}_{1}$ after methacholine $\left(\mathrm{r}_{\mathrm{S}}=-0.428\right)$; and with $\operatorname{IgE}\left(\mathrm{r}_{\mathrm{S}}=0.365\right)$ and $\operatorname{ECP}\left(\mathrm{r}_{\mathrm{s}}=0.554\right)$.

In the urine, total cysteinyl LTs in $\mathrm{pg} / \mathrm{ml}$ (but not $\mathrm{LTB}_{4}$ ) were significantly elevated before and after the methacholine challenge, but the difference disappeared when the markers were specified per mmol of creatinine in urine, as shown in Table 3.

In subjects with OA due to LMW agents, a younger age, lower ESR, and higher $\mathrm{FEV}_{1}$ were found.

The asthma severity grade at the follow-up in the subjects with OA due to HMW agents did not improve in any subject, it was stable in $25 \%$, and became poorer in $75 \%$ of

Table 3. Impaired parameters of lung functions and selected laboratory findings in the EBC, plasma and urine in the patients with occupational asthma and control subjects

\begin{tabular}{|c|c|c|c|c|c|c|}
\hline \multirow[t]{2}{*}{ Parameter } & \multicolumn{2}{|c|}{$\begin{array}{l}\text { Occupational asthma group } \\
(\mathrm{N}=43)\end{array}$} & \multicolumn{2}{|c|}{$\begin{array}{l}\text { Control group } \\
(\mathrm{N}=20)\end{array}$} & \multicolumn{2}{|c|}{$\mathrm{p}$} \\
\hline & $\mathrm{M}$ & $\mathrm{SD}$ & $\mathrm{M}$ & SD & t-test & K-W test \\
\hline $1 \mathrm{CRP}(\mathrm{mg} / \mathrm{l})$ & 3.18 & 2.30 & 2.57 & 4.35 & & $0.008^{* *}$ \\
\hline 1 Eosinophils $\left(\times 10^{9} / 1\right)$ & 0.23 & 0.18 & 0.18 & 0.10 & & \\
\hline $1 \mathrm{IgE}(\mathrm{IU} / \mathrm{ml})$ & 163.31 & 310.32 & 31.81 & 23.48 & $0.008^{*}$ & $<0.001^{* *}$ \\
\hline $1 \mathrm{ECP}(\mathrm{ng} / \mathrm{ml})$ & 33.97 & 17.31 & 24.41 & 18.17 & 0.049 & $0.009^{* *}$ \\
\hline $1 \mathrm{FEV}_{1}(\%)$ & 91.31 & 21.49 & 111.82 & 9.51 & $<0.001^{*}$ & $<0.001$ \\
\hline $1 \mathrm{MEF} 25(\%)$ & 51.51 & 23.69 & 81.54 & 21.67 & $<0.001$ & $<0.001$ \\
\hline 1 MEF50 (\%) & 65.23 & 28.59 & 95.96 & 19.74 & $<0.001$ & $<0.001$ \\
\hline $1 \mathrm{AEX}(\%)$ & 76.01 & 37.07 & 109.54 & 19.34 & $<0.001$ & $<0.001$ \\
\hline 1 Rtot $(\%)$ & 113.16 & 51.38 & 66.78 & 22.02 & $<0.001^{*}$ & $<0.001$ \\
\hline $1 \mathrm{FEV}_{1}(\mathrm{l})$ & 2.86 & 0.95 & 3.49 & 0.96 & 0.016 & 0.024 \\
\hline $2 \mathrm{FEV}_{1}(\mathrm{l})$ & 2.41 & 0.70 & 3.12 & 1.04 & $0.012^{*}$ & 0.015 \\
\hline 1 EBC 8-ISO (pg/ml) & 90.51 & 25.34 & 71.63 & 35.23 & 0.018 & $0.003^{* *}$ \\
\hline 2 EBC 8-ISO (pg/ml) & 84.50 & 23.28 & 63.96 & 17.93 & $<0.001$ & 0.001 \\
\hline $1 \mathrm{EBC} \mathrm{LTB}_{4}(\mathrm{pg} / \mathrm{ml})$ & 25.68 & 8.74 & 39.28 & 73.20 & & \\
\hline $2 \mathrm{EBC} \mathrm{LTB}_{4}(\mathrm{pg} / \mathrm{ml})$ & 24.54 & 7.57 & 26.59 & 7.65 & & \\
\hline 1 EBC Cys LT (pg/ml) & 165.73 & 30.96 & 158.46 & 118.01 & & $<0.001^{* *}$ \\
\hline 2 EBC Cys LT (pg/ml) & 155.87 & 40.23 & 145.08 & 39.66 & & \\
\hline $1 \mathrm{EBC} \mathrm{pH}$ & 5.84 & 0.46 & 5.85 & 0.35 & & \\
\hline $2 \mathrm{EBC} \mathrm{pH}$ & 5.62 & 0.50 & 5.96 & 0.39 & 0.009 & 0.007 \\
\hline $1 \mathrm{EBC} \mathrm{LTC}_{4}(\mathrm{pg} / \mathrm{ml})$ & 67.27 & 18.71 & 51.26 & 22.18 & 0.004 & $<0.001^{* *}$ \\
\hline
\end{tabular}


Table 3. Impaired parameters of lung functions and selected laboratory findings in the $\mathrm{EBC}$, plasma and urine in the patients with occupational asthma and control subjects - cont.

\begin{tabular}{|c|c|c|c|c|c|c|}
\hline \multirow[t]{2}{*}{ Parameter } & \multicolumn{2}{|c|}{$\begin{array}{l}\text { Occupational asthma group } \\
\qquad(\mathrm{N}=43)\end{array}$} & \multicolumn{2}{|c|}{$\begin{array}{l}\text { Control group } \\
(\mathrm{N}=20)\end{array}$} & \multicolumn{2}{|c|}{$\mathrm{p}$} \\
\hline & $\mathrm{M}$ & SD & $\mathrm{M}$ & $\mathrm{SD}$ & t-test & $\mathrm{K}-\mathrm{W}$ test \\
\hline 1 EBC MDA (ng/ml) & 22.43 & 9.81 & 14.78 & 5.46 & 0.002 & 0.001 \\
\hline 1 Plasma 8-ISO (pg/ml) & 55.38 & 13.63 & 48.65 & 17.03 & & $0.031^{* *}$ \\
\hline 1 Plasma HNE (ng/ml) & 56.52 & 19.28 & 66.53 & 17.59 & & $0.031^{* *}$ \\
\hline 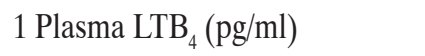 & 39.42 & 12.01 & 43.76 & 17.56 & & \\
\hline 2 Plasma $\mathrm{LTB}_{4}(\mathrm{pg} / \mathrm{ml})$ & 41.08 & 12.38 & 43.54 & 17.99 & & \\
\hline 1 Plasma Cys LT (pg/ml) & 196.48 & 26.64 & 181.61 & 31.89 & & \\
\hline 2 Plasma Cys LT (pg/ml) & 195.29 & 24.97 & 179.25 & 33.58 & 0.038 & $0.045^{* *}$ \\
\hline 1 Urine $\mathrm{LTB}_{4}(\mathrm{ng} / \mathrm{mmol}$ creat $)$ & 46.77 & 27.92 & 41.03 & 27.36 & & \\
\hline 2 Urine $\mathrm{LTB}_{4}(\mathrm{ng} / \mathrm{mmol}$ creat $)$ & 53.16 & 36.38 & 64.77 & 103.62 & & \\
\hline 1 Urine Cys LT (ng/mmol creat) & 39.15 & 20.85 & 35.25 & 19.76 & & \\
\hline 2 Urine Cys LT (ng/mmol creat) & 44.93 & 32.79 & 49.32 & 59.73 & & \\
\hline
\end{tabular}

1 - Measurement 1 (before methacholine challenge), 2 - Measurement 2 (after methacholine challenge).

$\mathrm{CRP}$ - C reactive protein; \% - percent predicted; $\mathrm{FEV}_{1}$ - forced expiratory volume in 1 second; MEF $25 \%$ - maximal expiratory flow rate at $25 \%$ of the vital capacity; MEF50\% - maximal expiratory flow rate at 50\% of the vital capacity; AEX\% - area under the maximum expiratory flow-volume curve; Rtot \% - total airway resistance; LT - leukotriene; Cys LT - cysteinyl leukotriene; EBC - exhaled breath condensate; MDA - malondialdehyde; 8-ISO - 8-iso-prostaglandin $\mathrm{F}_{2 \alpha}$; $\mathrm{HNE}$ - 4-hydroxy-trans-2-nonenale; creat. - creatinine.

P-values are provided for T-tests with or without assumption of equal variances in both groups and alternatively for Kruskal-Wallis (relevant in situation if tests based on skewness, curtosis and Kolmogorov-Smirnov strictly do not reject the normality assumption).

* Indicates T-tests with equal variances not assumed (due to rejection of F-test).

** Indicates the normality assumption does not hold (only Kruskal-Wallis test is relevant).

the subjects. In the subjects with OA due to LMW agents, the severity grade improved in $11 \%$, was stable in $47 \%$ and deteriorated in $42 \%$ of the patients.

Prick tests at the follow-up in patients with OA due to HMW agents (including new allergens) were positive in $71 \%$ of those subjects ( $21 \%$ were negative, $8 \%$ were not tested); in the subjects with OA due to LMW agents, prick tests were positive in $58 \%$ of the subject (negative in 10\% of the subjects, and $32 \%$ of the subjects were not tested). The level of EBC markers did not differ significantly among the subjects with the severity 2 , severity 3 and severity 4 grades of asthma [20]. However, there was a trend in the increase that was seen both in the pre-challenge EBC 8-ISO $(132 \pm 32 \mathrm{pg}, 144 \pm 21 \mathrm{pg}$ and $155 \pm 52 \mathrm{pg})$, respectively, in EBC cysteinyl LTs ( $240 \pm 40 \mathrm{pg}, 258 \pm 28 \mathrm{pg}$ and $330 \pm 170 \mathrm{pg}$ ), respectively and in plasma cysteinyl LTs $(189 \pm 14 \mathrm{pg}, 195 \pm 10 \mathrm{pg}$, and $216 \pm 34 \mathrm{pg}$ ), respectively.

Accordingly, in the trend of asthma severity grade, prechallenge EBC 8-ISO was $137 \pm 26 \mathrm{pg}$ in those who were stable, and $145 \pm 21 \mathrm{pg}$ in those who got worse. Similarly, this trend was seen in EBC cysteinyl LTs $=252 \pm 37 \mathrm{pg}$ and $266 \pm 31 \mathrm{pg}$ and plasma cysteinyl LTs $=190 \pm 12 \mathrm{pg}$ and $201 \pm 11$ pg before the challenge.

The influence of corticosteroid treatment, vitamin $\mathrm{C}$ and vitamin $\mathrm{E}$, and smoking on all oxidative stress markers in the EBC was not significant $(p \geq 0.05)$, with the exception of HNE, which was lower ( $p=0.042$ at $t$-test) in corticosteroid-treated patients. 


\section{DISCUSSION}

Follow-up of the patients with OA typically involves evaluation of lung function, blood eosinophils, IgE, ECP, methacholine challenge, treatment history and medication doses. In addition, FeNO have become easily available and may provide important information about how OA is controlled. Unfortunately, not only the corticosteroid treatment, but also smoking decreases the result [8]. Our data show that the measurements of LTs, 8-ISO and other markers of oxidative stress in $\mathrm{EBC}$ may reflect the pathophysiological process of OA and provide the insights into its severity. According to these data, classical parameters, such as total IgE and ECP are also important.

These results confirm that the removal of the patient with OA from the contact with the specific allergen does not lead to an early recovery. A significant obstructive ventilatory impairment may persist for longer than 10 years.

The most important markers in the EBC were cysteinyl LTs and 8-ISO; these markers were elevated initially and also after the methacholine challenge. Similarly, MDA and $\mathrm{LTC}_{4}$, which were increased in the patients before the challenge, probably reflect the level of oxidative stress due to OA.

It is not advisable to stop the therapy in all OA patients for several weeks before the follow-up examination merely for the purpose of compensation. In our patients, the pharmacological treatment was continued in about $90 \%$ of the subjects longer than for 10 years after OA had been diagnosed. The 8-ISO and cysteinyl LTs in OA patients were not suppressed with corticosteroid treatment, which witnesses the practical utility of these markers for this purpose.

Also plasma 8-ISO could be used for the evaluation of the inflammation and oxidative stress in $\mathrm{OA}$, as significant difference was seen between patients with and without the provocation, and plasma 8-ISO correlated with lower $\mathrm{FEV}_{1}$ and lower methacholine $\mathrm{PD}_{20}$.
On the other hand, $\mathrm{pH}$ significantly differed in the two groups of subjects solely after the methacholine test; therefore this easily measurable parameter could not be used as an isolated marker.

Unlike in a study with allergen inhalation [29], urinary LTs were not increased in our study and do not appear useful in the follow-up. Similarly, LTB $_{4}$ cannot be used, which is in agreement with its role especially in COPD.

According to some parameters, including asthma severity, the prognosis for LMW agent-related OA was better than that for HMW agent-related OA, even if $\mathrm{FEV}_{1}$ of the two groups of patients did not significantly differ at the time of diagnosis. The explanation may be in the fact that the elimination of LMW agents was easier, as LMW agents were limited to the occupation (unlike flour, common in the households). Anyway, all subjects with OA tried to minimize the exposure to these ubiquitous allergens.

To conclude, no isolated marker is able to express the severity/activity and level of control of OA and the effect of elimination of the allergen. A set of markers and measurements is required to achieve those objectives. The 8-ISO in the EBC and in the plasma, and cysteinyl LTs in the EBC might enrich the spectrum of objective tests for the follow-up of OA to quantify the severity of inflammation and oxidative stress in the airways. These markers might represent a non-invasive substitution for methacholine challenge.

\section{REFERENCES}

1. Fenclová Z, Urban P, Pelclová D, Voriskova M, Havlová D. [Occupational diseases reported in the Czech Republic in 2012]. Prakt Lék. 2013;93(3):93-9. Czech.

2. Klusáčková P, Lebedová J, Pelclová D, Šalandová J, Šenholdová Z, Navrátil T. Occupational asthma and rhinitis in workers from a lasamide production line. Scand J Work Environ Health. 2007;33(1):74-8. 
3. Talini D, Novelli F, Melosini L, Bacci E, Bartoli ML, Cianchetti S, et al. May the reduction of exposure to specific sensitizers be an alternative to work cessation in occupational asthma? Results from a follow-up study. Int Arch Allergy Immunol. 2012;157(2):186-93, http://dx.doi.org/10.1159/000327550.

4. Klusáčková P, Pelclová D, Lebedová J, Marečková H, Brabec M. Occupational asthma after withdrawal from the occupational allergen exposure. Ind Health. 2006;44(4):629-38, http://dx.doi.org/10.2486/indhealth.44.629.

5. Krakowiak A, Walusiak J, Krawczyk P, Wiszniewska M, Dudek W, Wittczak T, et al. IL-18 levels in nasal lavage after inhalatory challenge test with flour in bakers diagnosed with occupational asthma. Int J Occup Med Environ Health. 2008;21(2):165-72, http://dx.doi.org/10.2478/ v10001-008-0015-y.

6. Świerczyńska-Machura D, Krakowiak A, Wiszniewska M, Dudek W, Walusiak J, Pałczyński C. Exhaled nitric oxide levels after specific inahalatory challenge test in subjects with diagnosed occupational asthma. Int J Occup Med Environ Health. 2008;21(3):219-25, http://dx.doi.org/10.2478/ v10001-008-0024-x.

7. Čáp P, Chládek J, Pehal F, Malý M, Petrů V, Barnes PJ, et al. Gas chromatography/mass spectrometry analysis of exhaled leukotrienes in asthmatic patients. Thorax. 2004;59(6): 465-70, http://dx.doi.org/10.1136/thx.2003.011866.

8. Al-Samri MT, Benedetti A, Préfontaine D, Olivenstein R, Lemière $\mathrm{C}$, Nair $\mathrm{P}$, et al. Variability of sputum inflammatory cells in asthmatic patients receiving corticosteroid therapy: A prospective study using multiple samples. J Allergy Clin Immunol. 2010;125(5):1161-3， http://dx.doi.org/10.1016/ j.jaci.2010.02.005.

9. Lemiere C, Chaboillez S, Welman M, Maghni K. Outcome of occupational asthma after removal from exposure: A follow-up study. Can Respir J. 2010:17(2):61-6.

10. Kharitonov SA, Barnes PJ. Exhaled markers of pulmonary disease. Am J Respir Crit Care Med. 2001;163(7):1693-722.

11. Horvath I, Hunt J, Barnes PJ. Exhaled breath condensate: methodological recommendations and unresolved questions. Eur Res J. 2005;26(3):523-48, http://dx.doi.org/ 10.1183/09031936.05.00029705.

12. Antczak A, Górski P. Markers of pulmonary diseases in exhaled breath condensate. Int J Occup Med Environ Health. 2002;15(4):317-23.

13. Holgate ST, Peter-Golden M, Panettieri RA, Henderson WR. Roles of cysteinyl leukotrienes in airway inflammation, smooth muscle function, and remodeling. J Allergy Clin Immunol. 2003;111(Suppl):S18-36.

14. Carpagnano GE, Kharitonov SA, Foschino-Barbaro MP, Resta O, Gramiccioni E, Barnes PJ. Increased inflammatory markers in the exhaled breath condensate of cigarette smokers. Eur Respir J. 2003;21(4):589-93, http://dx.doi.org/10.11 83/09031936.03.00022203.

15. Montuschi P. Exhaled breath condensate: 8-isoprostane and eicosanoids. In: Horvath I, de Jongste JC, editors. Exhaled Biomarkers. Eur Respir Soc Monogr. 2010;49:196-206, http://dx.doi.org/10.1183/1025448x.00011210.

16. Baraldi E, Ghiro L, Piovan V, Carraro S, Ciabattoni G, Barnes PJ, et al. Increased exhaled 8-isoprostane in childhood asthma. Chest. 2003;124(1):25-31, http://dx.doi. org/10.1378/chest.124.1.25.

17. Klusáčková P, Lebedová J, Kačer P, Kuzma M, Brabec M, Pelclová $\mathrm{D}$, et al. Leukotrienes and 8-isoprostane in exhaled breath condensate in bronchoprovocation tests with occupational allergens. Prostaglandins Leukot Essent Fatty Acids. 2008;78 (4-5):281-92, http://dx.doi.org/10.1016/j.plefa.2008.03.006.

18. Battaglia S, den Hertog H, Timmers MC, Lazeroms SPG, Vignola AM, Rabe KF, et al. Small airways function and molecular markers in exhaled air in mild asthma. Thorax. 2005;60(8):639-44, http://dx.doi.org/10.1136/ thx.2004.035279.

19. Bousquet J, Heinzerling L, Bachert C, Papadopoulos NG, Bousquet PJ, Burney PG, et al. Global Allergy and Asthma European Network; Allergic Rhinitis and its Impact on Asthma. Practical guide to skin prick tests in allergy to aeroallergens. Allergy. 2012;67(1):18-24, http://dx.doi. org/10.1111/j.1398-9995.2011.02728.x. 
20. Le Moual N, Siroux V, Pin I, Kauffmann F, Kennedy SM. Epidemiological study on the genetics and environment of asthma. Asthma severity and exposure to occupational asthmogens. Am J Respir Crit Care Med. 2005;172(4):440-5.

21. Quanjer PH, Tammeling GJ, Cotes JE, Pedersen OF, Peslin R, Yernault JC. Lung volumes and forced ventilatory flows. Report working party. Standardization of Lung Function Tests. European Community for Steel and Coal. Official Statement of the European Respiratory Society. Eur Respir J. 1993;6(Suppl 16):5-40.

22. Cockcroft DW, Killian DN, Mellon JJ, Hargreave FE. Bronchial reactivity to histamine: A method and clinical survey. Clin Allergy. 1977;7(3):235-43, http://dx.doi. org/10.1111/j.1365-2222.1977.tb01448.x.

23. Sterk PJ, Fabbri LM, Quanjer PhH, Cockcroft DW, O'Byrne PM, Anderson SD, et al. Airway Responsiveness. Standardized challenge testing with pharmacological, physical and sensitizing stimuli in adults. Report Working Party. Standardization of Lung Function Tests. European Community for Steel and Coal. Official Statement of the European Respiratory Society. Eur Respir J. 1993;6(Suppl 16):53-83.

24. APS Instruction manual 1986, version 2, Art. No. 780092, Erich Jaeger GmbH\&Co Höchberg.

25. Syslová K, Kačer P, Kuzma M, Pankrácová A, Fenclová Z, Vlčková S, et al. LC-ESI-MS/MS method for oxidative stress multimarker screening in the exhaled breath condensate of asbestosis/silicosis patients. J Breath Res. 2010;4(1):017104, http://dx.doi.org/10.1088/1752-7155/4/1/017104.
26. Syslová K, Kačer P, Vilhanová B, Kuzma M, Lipovová $\mathrm{P}$, Fenclová Z, et al. Determination of cysteinyl leukotrienes in exhaled breath condensate: method combining immunoseparation with LC-ESI-MS/MS. J Chromatogr B. 2011;879(23):2220-8, http://dx.doi.org/10.1016/ j.jchromb.2011.06.004.

27. Syslová K, Kačer P, Kuzma M, Lebedová J, Klusáčková P, Fenclová Z, et al. Determination of 8-iso-prostaglandin F2a in exhaled breath condensate by method combining immunoseparation with LC-ESI-MS. J Chromatogr B. 2008;867(1):8-14, http://dx.doi.org/10.1016/ j.jchromb.2008.02.019.

28. Syslová K, Kačer P, Kuzma M, Najmanová V, Fenclová Z, Vlčková $\mathrm{S}$, et al. Rapid and easy method for monitoring oxidative stress markers in body fluids of patients with asbestos or silica-induced lung diseases. J Chromatogr B. 2009;877(24):2477-86, http://dx.doi.org/10.1016/ j.jchromb.2009.06.008.

29. Ono E, Mita H, Taniguchi M, Higashi N, Tsuburai T, Hasegawa $\mathrm{M}$, et al. Increase in inflammatory mediator concentrations in exhaled breath condensate after allergen inhalation. J Allergy Clin Immunol. 2008;122(4):768-73, http://dx.doi. org/10.1016/j.jaci.2008.06.009.
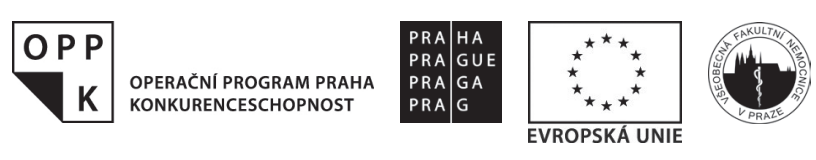

This work is available in Open Access model and licensed under a Creative Commons Attribution-NonCommercial 3.0 Poland License - http://creativecommons.org/ licenses/by-nc/3.0/pl/deed.en. 